
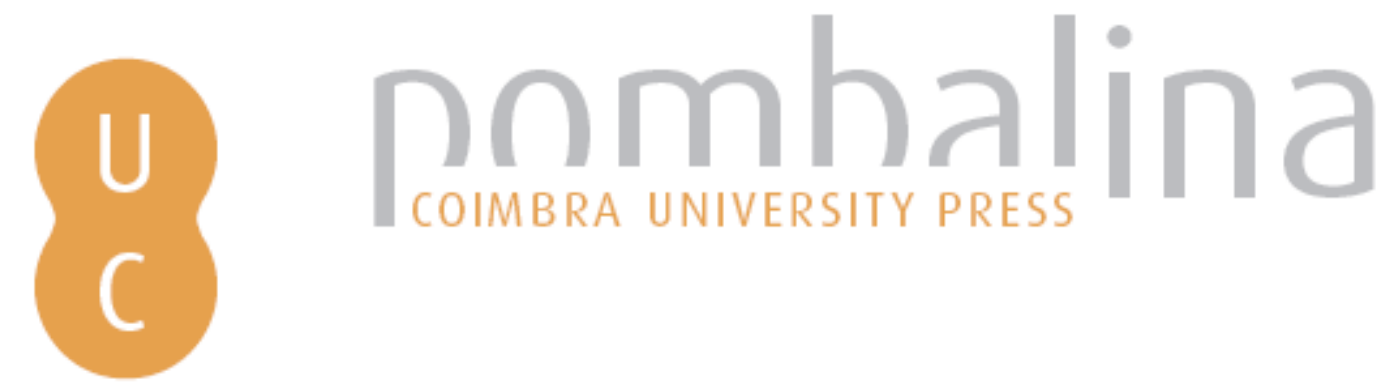

\title{
A rare case of traumatic laceration of intracranial vertebral artery in absence of pathologies and directed traumas to the head
}

Autor(es): $\quad$ Andrello, L.; Minonzio, G.; Algisi, N.; Tajana, L.; Osculati, A.

Publicado por: Imprensa da Universidade de Coimbra

URL

persistente: URI:http://hdl.handle.net/10316.2/31732

DOI: $\quad$ DOI:http://dx.doi.org/10.14195/978-989-26-0173-1_74

Accessed : $\quad$ 26-Apr-2023 13:46:22

A navegação consulta e descarregamento dos títulos inseridos nas Bibliotecas Digitais UC Digitalis, UC Pombalina e UC Impactum, pressupõem a aceitação plena e sem reservas dos Termos e Condições de Uso destas Bibliotecas Digitais, disponíveis em https://digitalis.uc.pt/pt-pt/termos.

Conforme exposto nos referidos Termos e Condições de Uso, o descarregamento de títulos de acesso restrito requer uma licença válida de autorização devendo o utilizador aceder ao(s) documento(s) a partir de um endereço de IP da instituição detentora da supramencionada licença.

Ao utilizador é apenas permitido o descarregamento para uso pessoal, pelo que o emprego do(s) título(s) descarregado(s) para outro fim, designadamente comercial, carece de autorização do respetivo autor ou editor da obra.

Na medida em que todas as obras da UC Digitalis se encontram protegidas pelo Código do Direito de Autor e Direitos Conexos e demais legislação aplicável, toda a cópia, parcial ou total, deste documento, nos casos em que é legalmente admitida, deverá conter ou fazer-se acompanhar por este aviso.

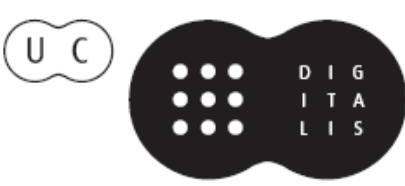




\section{Duarte Nuno Vieira Anthony Busuttil \\ Denis Cusack • Philip Beth}
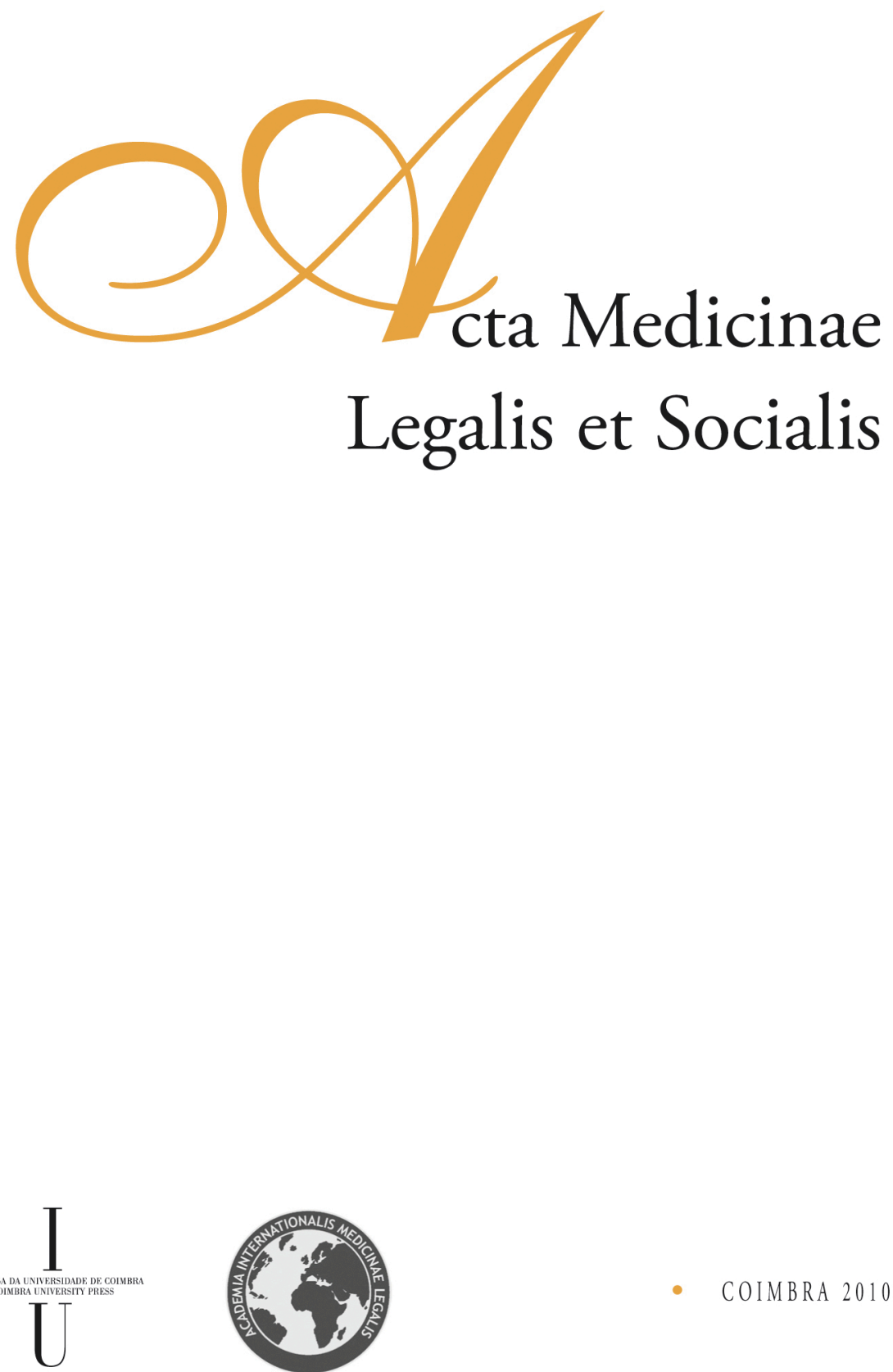
L. Andrello ${ }^{1}$, G. Minonzio ${ }^{2}$, N. Algisi ${ }^{1}$, L. Tajana ${ }^{1}$, A. Osculati ${ }^{1}$

${ }^{1}$ Department of Medicine and Public Health, Legal Medicine Unit, University of Insubria, Varese, Italy

${ }^{2}$ Neuroradiology Unit, S. Antonio Abate Hospital, Gallarate, Varese, Italy

\title{
A RARE CASE OF TRAUMATIC LACERATION OF INTRACRANIAL VERTEBRAL ARTERY IN ABSENCE OF PATHOLOGIES AND DIRECTED TRAUMAS TO THE HEAD
}

\begin{abstract}
We present a rare case of death of a young healthy man, due to massive cerebral haemorrhage from the breaking of the intracanical vertebral artery, followed to a scuffle in which there were not produced directed traumas of such violence to explain the laceration of the vessel with a direct bruising mechanism.

A very thorough study of the case allowed us to exclude structural weaknesses of the part of the interested artery and obliged to assume a mechanism of abnormal mobilization of the head by traumatic origin that determined an abnormal stretching of the vessel with consequent laceration of the same one with lethal outcome. We presented the intravitam cerebrovascular imaging study and the post-mortal MRI examination and one possible reconstruction of the dynamic. Only the combined use of many radiological and histopathological techniques can assumed complex aetiopathogenetic mechanisms in the genesis of intracranical vascular injuries, excluding predisposing natural factors.
\end{abstract}

\section{Case report}

On the second of February 2008, in the Saturday morning a prosecuting attorney of Swiss Canton Ticino Procuration asked us to visit a twenty-two years old boy at Bellinzona's Hospital. The boy was assaulted by three young boys, around midnight, during citizen Carnival's celebration.

When we arrived at the hospital, around ten a.m., the doctor told us that the cerebral death observation period has already began. Patient brain CT scan pointed out a massive brain haemorrhage, with the discharge of the contrast liquid from left vertebral artery with very abundant cerebral aedema. (Fig 1,2)

The neurological examination demonstrated the absence of brain and brainstem reflexes, and a Glasgow Coma Scale of three.

We proceeded to visit accurately the young boy, who presented:

- at the left fronto-temporal region a slender reddish abrasion; (Fig 3)

- at the chest, at right parasternal and at left lateral region two slender erithematous lesions few centimetres wide; 
- at the left elbow a 1 centimetre exchoriation;

- at the right hand, in correspondence of the 3rd, 4th and 5th metacarpalphalangeal articulation, other little exchoriations; (Fig 4)

- at the front face of the left leg, three little abrasions of 3 centimetres maximal dimension.

In the evening of the same day was declared the death of the boy and we gave positive opinion for the organs explantation, after previewing all done examinations. So, at Sunday morning, heart, lungs, liver, pancreas and kidneys were explanted.

In the Monday morning, we performed the autopsy (Fig 5). During external examination, besides the lesions pointed out the day before, we saw:

- at the distal third of the left arm, on the posterior face, an irregular $8 \times 5$ centimetres wide ecchymosis (Fig 6);

- at the right gluteal region an irregular 5 x 3 centimetres ecchymosis.

The autopsy revealed, beside the absence of intrathoracic and intra-abdominal organs:

- a slender haematic infiltration of the left deep scalp tissues and the left temporal muscle, under the bruise described before (Fig 7);

- a very abundant sub-arachnoid haemorrhage. The whole brain was taken and fixed in formalin buffered solution in order to do other specialistic examinations (Fig 8,9);

- at the neck region, in absence of visible injuries, beside the routinary section, we did a postero-lateral section of the skin, that pointed out a slender haematic infiltration of superior fascicles of left trapezius muscle, of splenius capitis and the semispinal capitis;

- another skin postero-median section pointed out a slender haematic infiltration of median muscles deep fascicles and of its contiguos left portion (Fig 10).

After other two weeks, we proceeded to the exposition of brainstem and cerebellum vascular structures, removing the coagulated blood to locate the cerebral haemorrhage source.

This research was done with the help of a neuroradiologist, who ri-edited the CT examination done at the Bellinzona's Hospital and he indicated us the probable point of the vertebral artery laceration (Fig 11,12,13).

So, we catheterized the distal tract of the left vertebral artery and we injected water with slow pressure and we saw the discharge at the intracranial tract of the left vertebral artery, about two centimetres distally to the basilar artery. We observed a laceration in the lateral slope of the artery wall of 0.3 centimetres length. We observed also an hypoplasia of the right vertebral artery, an antomical variant widely described in literature (Fig 14).

After this study we took same samples of the vessel's wall to perform histological examinations by an expert pathologist. These examinations pointed out no alterations of vessel structures, due to both genetic and acquired diseases that could cause a reduced tensil strength of the wall to moderate trauma (Fig 15,16). 


\section{Conclusions}

In conclusion the cause of death was certainly the cerebral haemorrhage from intracranial left vertebral artery laceration. The slender injuries found on the corpse, bring us to assume that the vessel lesion was caused by a very quick and abnormal movement of neck and head, determining extreme traction on the artery wall behind the tension maximum limit of the vessel and so its laceration.

This hypothesis was supported by the signalling of same similar cases published in international journals, in which the intracranial vertebral artery laceration was caused by minor traumas (also the whiplash), in absence of genetic diseases (such as Marfan and Elher-Danlos syndrome) or acquired diseases (such as aneurysm) of the vessel.

In this case the movement was determined, like to demonstrate in court, by three boys who landed some punches and lashed out at the victim. The sentence of first degree acknowledged boys' guilt, sentencing them to ten years' imprisonment.

\section{References}

ANXIONNAT R, DE MELO NETO J F, BRACARD S, LACOUR J C, PINELLI C, CIVIT T, PICARD L; Treatment of hemorrhagic intracranial dissection; Neurosurgery; 53 (3); 289-301, aug 2003.

ASAI T, KATAOKA K, UEJIMA T, SAKATA I, TANEDA M; Traumatic laceration of the intracranial vertebral artery causing fatal subarachnoid hemorrage: case report; Surgical Neurology; 45(6); 566-569, jun 1996.

BIFFI W L, MOORE E E, ELLIOT J P, RAY C, OFFNER P J, FRANCIORE R J, BREGA K E, BURCH J M; The devasting potential of blunt vertebral arterial injuries; Annals of Surgery; 31(5); 672-681, may 2000.

BIFFI W L, RAY C EJR, MOORE E E, FRANCIOSE R J, ALY S, HEYROSA M G, JOHNSON J L, BURCH J M; Treatment-related outcomes from blunt cerebrovascular injuries. Importance of routine follow-up arteriography; Annals of Surgery; 235 (5); 699-70, may 2000.

BUNAI Y, NAGAI A, NAKAMURA I, OHYA I; Traumatic rupture of the basilar artery; report of two case and rewiew of the literature; Am J Forensic Med Pathol; 21(4); 343-348, dec 2000.

COAST G C, GEE D J; Traumatic subarachnoid haemorrage: an alternative source; J Clin Patho; 37; 1245-1248, 1984.

COLLIN K A, SELLERS K; Vertebral artery laceration mimicking elder abuse; Am J Forensic Med Pathol; 26(2); 150-154, jun 2000.

COTHREN C C; MOORE E E, BIFFI W L, CIESLA D J, RAY C E JR.; MOORE J B, BURCH J M J; Cervical spine fracture patterns predictive of blunt vertebral artery injury; J Trauma; 55(5); 811-813, nov 2003.

DA COSTA L B, TYMIANSKI M; Symptomatic non-atherosclerotic bilateral extracranial vertebral artery occlusion treated with extracranial to intracranial bypass; Arq Neuropsiquiatr; 64(3-A); 664-667, 2006.

DECK J H, JAGADHA V; Fatal subarachnoid hemorrhage due to traumatic rupture of the vertebral artery; Arch Pathol Lab Med; 110(6); 489-493, jun 1986.

DOWLING G, CURRY B; Traumatic basal subarchnoid hemorrhage. Report of six cases and rewiew of the literature; Am J Forensic Med Pathol; 9(1); 23-31, mar 1988. 
EGUCHI K, TACHIKAWA Y, KASHIMA R, SHINOHARA M, FUKUSHIMA F, SATO T, TAKEDA A, NUMAO T, KARIO K, SHIMADA K; A case of vertebral artery dissection associated with morning blood pressure surge; Hypertens Res; 28(10); 847-851; 2005

HIRAIWA K, SATO T, SASAKI T, MIZUSAWA I, NATA M, KODAMA N; Medico-legal aspects of traumatic injury of the vertebrobasilar artery; Neurol Med Chir.(Tokyo); 45; 549-555, nov 2005.

IWASE H, KOBAYASHI M, KURATA A. INOUE S; Clinically unidentified dissection of vertebral artery as a cause of cerebellar infarction; Stroke; 32(6); 1422-1424; jun 2001.

KINDELBERGER D, GILMORE K, CATANESE C A, ARBRUSTMACHER V W; Hypertension and rotation of head causing internal carotid artery laceration with basilar subarachnoid hematoma; J Forensic Sci; 48(3); 1366-1368, nov 2003.

MAXEINER H; Extra- ed intracranial injuries of the cerebral arteries as a sequela of assault; Z Rechtsmed; 102(2-3); 191-198, 1989.

MILLER P R, FABIAN T C, CROCE M A, CAGIANNOS C, WILLIAM S C, VANG M, QAISI W G, FELKER R E, TIMMONS S D; Prospective screening for blunt cerebrovascular injuries. Analysis of diagnostic modalities and outcomes; Annals of Surgery; 236 (3); 386395, sept 2002.

MIYAMOTO S, YASUDA M, TSUNODA T, KUSUNOKI H, SASAKI M; A child case of subarachnoid hemorrhage triggered by head injury: a case report; No Shinkei Gek; 29(8); 735-739, aug 2001.

MIYAZAKI T, KOJIMA T, CHIKASUE F, YASHIKI M, ITO H; Traumatic rupture of intracranial vertebral artery due to hypertension of the head: report on three case; Forensic Sci Int; 47(1); 91-98, aug 2000.

OGIICHI T, ENDO S, ONIZUKA K, TAKABA M, TAKAKU A, YASUDA M; Non-aneurysmal subarachnoid hemorrage associated with basilar artery dissection; Neurol Med Chir (Tokyo); 37; 612-615, 1997.

PLAZA I, DIEZ-TEJEDOR E, LARA M, BARREIRO P; Spontaneous dissection of the vertebral artery; Rev Neurol; 24(126); 163-171, feb 1996

PRABHAKAR S, BHATIA R, KHANDELWAL N, LAL V, DAS C P; Vertebral artery dissection due to indirect neck trauma: an underrecognised entity; Neurology India; 49(4); 384-390, dec 2001.

REDEKOP G, TERBRUGGE K, WILLINSKY R; Subarachnoid hemorrhage from vertebrobasilar dissecting aneurysm treated with staged bilateral vertebral artery occlusion: the importance of early follow-up angiography: technical case report; Neurosurgery; 45(5); 1258-1263, nov 1999.

RO A, KAGEYAMA N, HAYASHI K, SHIGETA A, FUKUNAGA T; Non-traumatic rupture of the intracranial vertebral artery of a man found dead in a severe car accident-histopatological differentiation by step-serial sections; Legal Medicine (Tokyo); 10(2); 101-106; mar 2008.

SAHJPAUL R L, ABDULAHAK M M, DRAKE C G, HAMMOND R R; Fatal traumatic vertebral artery aneurysm rupture. Case report; J Neurosurg; 89(5); 822-824, nov 1998.

TAKAHARA T, TERAI C, OKADA Y, MIMURA K, MUKAIDA M; Fatal traumatic subarchnoid hemorrhage due to rupture of the vertebral artery; Intensive Care Med; 19 (3);172-173, 1993.

YASUI T, SAKAMOTO H, KISHI H, KOMIYAMA M, IWAI Y, YAMANAKA K, NISHIKAWA $\mathrm{M}$; Bilateral dissecting aneurysms of the vertebral arteries resulting in subarachnoid hemmorrhage: case report; Neurosurgery; 42(1); 162-165, jan 1998.

ZHAO W Y, KRINGS T, ALVAREZ H, OZANNE A, HOLMIN S, LASJAUNIAS P; Management of spontaneous haemmorrhagic intracranial vertebrobasilar dissection: review of 21 consecutive case; Acta Neurochir; 149(1); 585-596, jun 2007. 

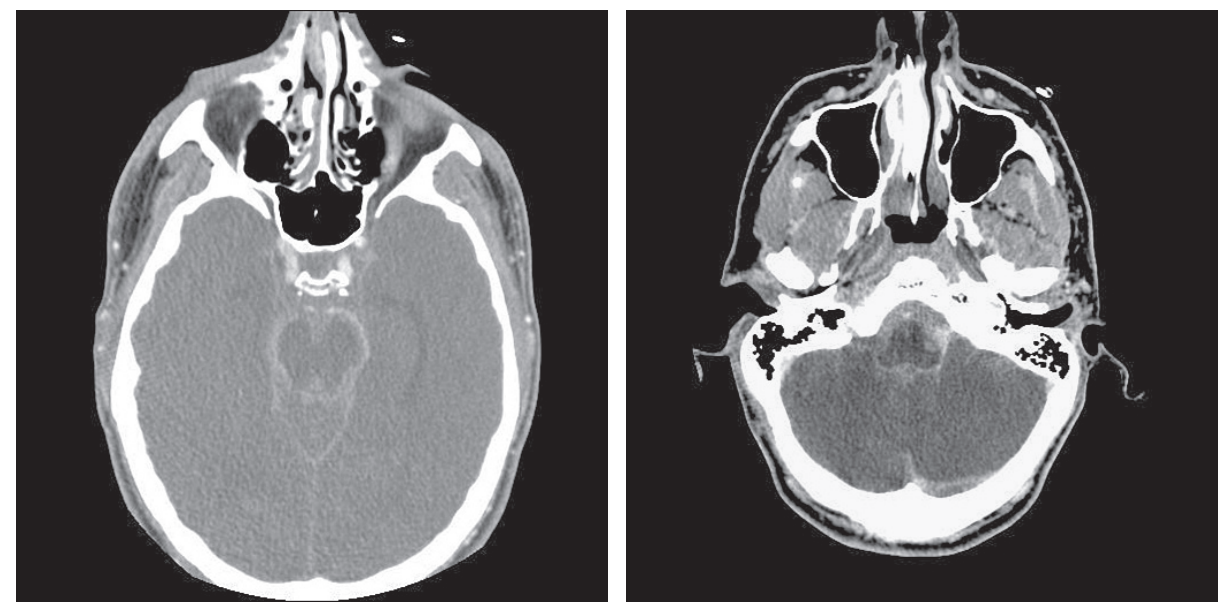

Figure 1,2 - brain CT scan: a massive brain haemorrhage, with the discharge of the contrast liquid from left vertebral artery with very abundant cerebral aedema.

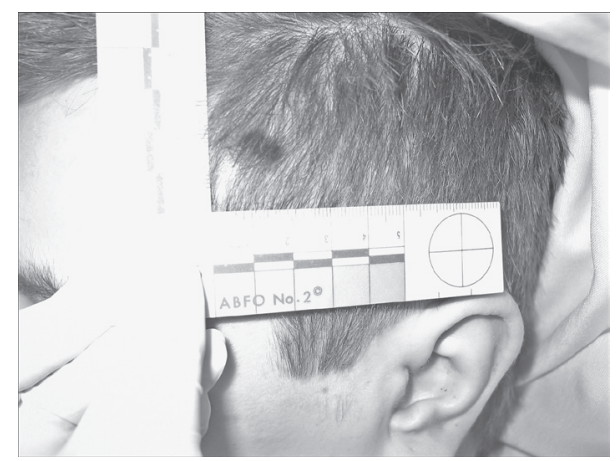

Figure 3 - a slender reddish abrasion at the left fronto-temporal region.

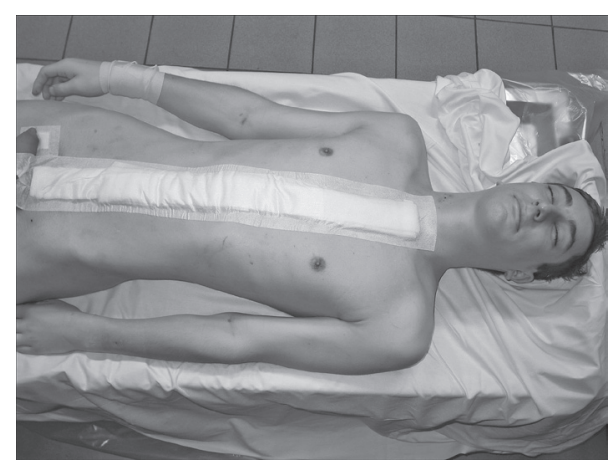

Figure 5 - the cadaver before the autopsy.

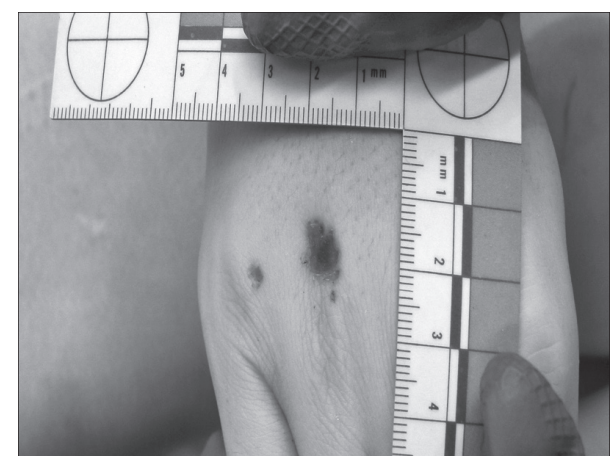

Figure 4 - little exchoriations at the right hand, in correspondence of the $3 \mathrm{rd}$, 4th and 5 th metacarpalphalangeal articulation 


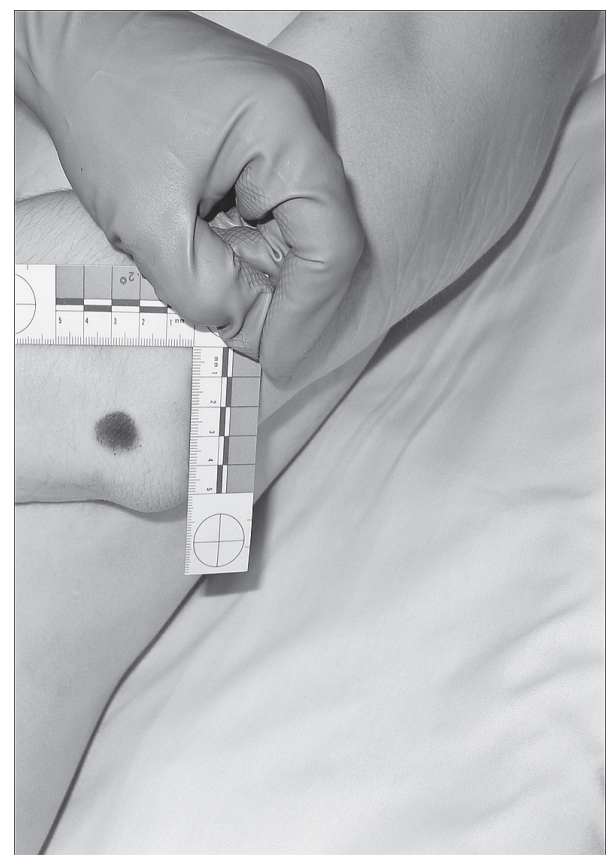

Figure 6 - irregular $8 \times 5$ centimetres ecchymosis at distal third of left arm, on posterior face.

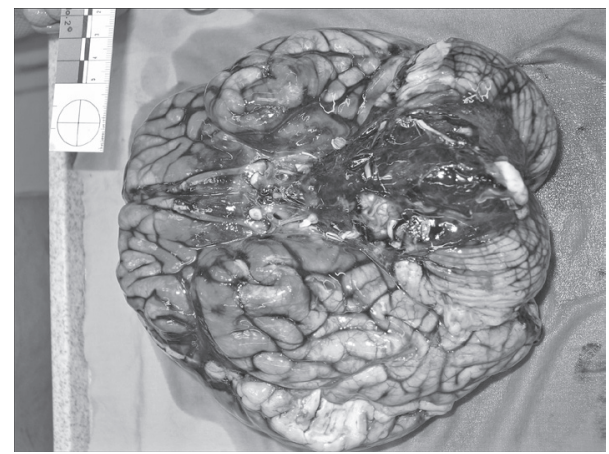

Figure 9 - isolated brain: cerebellum and brainstem haemorrhage.

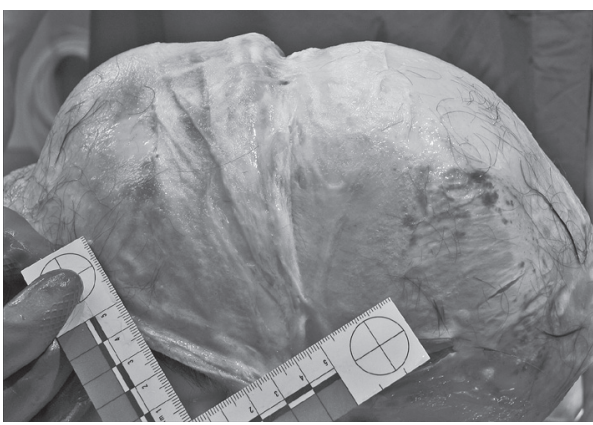

Figure 7 - a slender haematic infiltration of left deep scalp tissues and left temporal muscle.

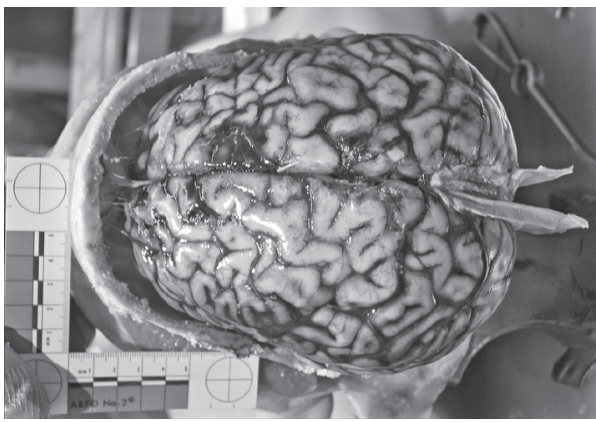

Figure 8 - in situ brain: a very abundant subarachnoid haemorrhage.

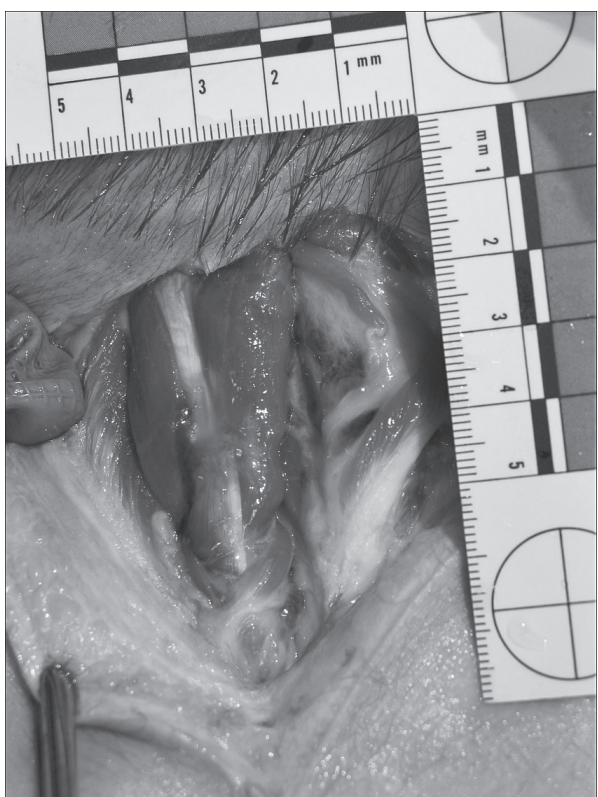

Figure 10 - skin postero-median section: a slender haematic infiltration of median muscles deep fascicles and of its contiguos left portion. 

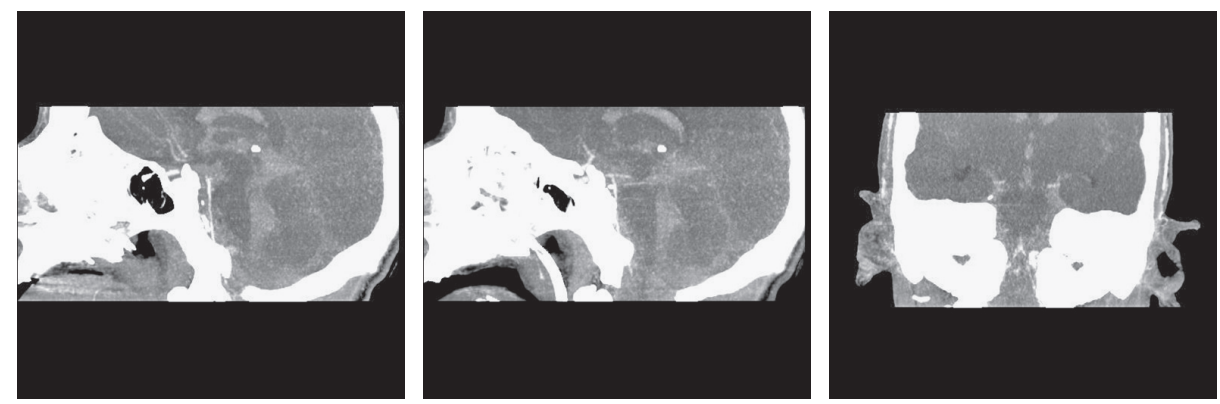

Figure 11-12-13 - ri-editing by neuroradiologist of CT scan done at the Bellinzona's Hospital; the specialist indicated us the probable point of vertebral artery laceration.

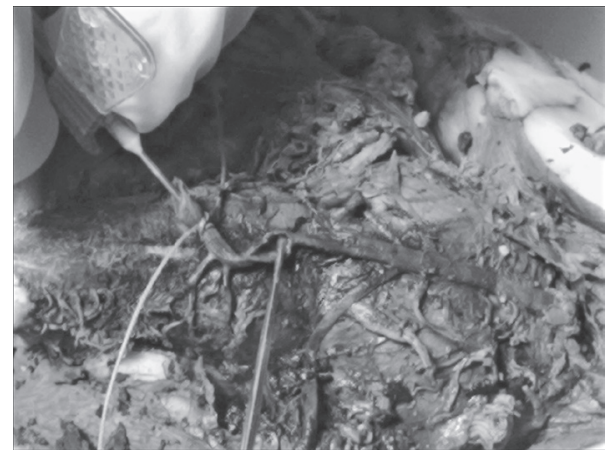

Figure 14 - the injection of water in left vertebral artery: the discharge of liquid from laceration.

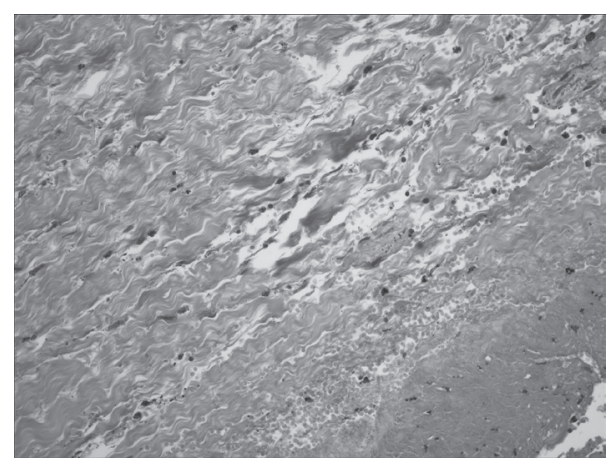

Figure 16 - histological examination (400x): further magnification of vessel's wall of left vertebral artery.

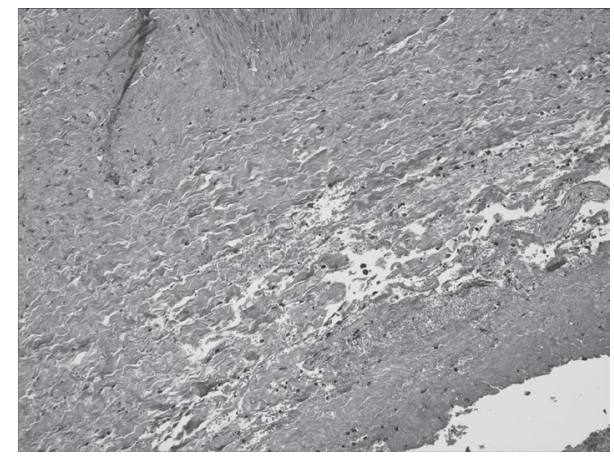

Figure 15 -histological examination (200x): normal vessel's wall of left vertebral artery. 